\title{
NEW PERSPECTIVE ARTICLE Hydrofluoric Acid - Simple Things You May Do Not Know About Something You Are So Habituated To Use
}

\author{
Ácido Hidrofluorhídrico - Cosas Simples Que Quizá Usted No Conoce \\ Acerca de Algo Que Está Tan Acostumbrado a Utilizar \\ Received: 15-VII-2015 Accepted: 15-VII-2015
}

\begin{abstract}
Hydrofluoric Acid (HF) acid usually is used to etch the internal surface of the ceramic restoration. This acid increases surface relief in micromechanical bonding of resin cement to ceramic restoration. Pre-treatment conditioning with HF in feldspathic ceramic and leucita reinforced glass-ceramic will result in an internal surface with white-opaque appearance. In this brief new perspective article we would discuss some important issues regarding HF use in dentistry.
\end{abstract}

\section{KEYWORDS}

Dental sciences; Bonding; pre-treatment conditioning; Hydrofluoric Acid

\section{RESUMEN}

El ácido fluorhídrico (HF) por lo general se utiliza para condicionar la superficie interna de la restauración cerámica. Este ácido promueve un cambio en la superficie de la cerámica la cual podría mejorar la unión micro-mecánica entre el cemento resinoso y la restauración de cerámica. El Pretratamiento con HF en la cerámica feldespática y en la vitro-cerámica reforzada con leucita puede resultar en una superficie interna con apariencia blanco-opaco. En este breve artículo se discutirá brevemente algunos puntos importantes relacionados con el uso de HF en odontología.

\section{PALABRAS CLAVE}

Ciencias Dentales; adhesión; pre-tratamiento de superficie cerámica; ácido fluorhídrico

The minimum thickness of a contact lens in e.max CAD is $0.4 \mathrm{~mm}$ (Ivoclar Vivadent, 2015). Considering this thickness, pre-treatment with 10\% hydrofluoric acid (HF) for 1 minute creates an over-conditioned ceramic surface (Perdigão, Ballarin \& Lopes, 2015). In this case, cracks propagation on ceramic are more likely to occur, than if the same ceramic piece was treated with 5\% HF for 20 sec (Perdigão, Ballarin \& Lopes, 2015). In the case of anterior teeth, after adhesive bonding, probably, there will be little difference as the contact lens becomes more resistant after proper photopolymerization of resin cement (Hill, Tysowsky \&, Costantino, 2009). Regarding 
retention criteria, there is no difference between both pre-treatment procedures (Lopes \& Perdigão, 2015). However, ceramic with thin thicknesses are hyper-fragile prior to cementation. It is necessary to perform manual pressure, in order to overflow excess of resin cement and place in position the ceramic piece properly. At this time, exists a probability to fracture the ceramic contact lens. Moreover in posterior teeth, thin over-conditioned onlays can potentially have early fractures during masticatory function. Thus, properly pre-treatment of the ceramic piece is a determining factor for clinical success.

\section{PRE-TREATMENT OF CERAMIC SURFACE}

HF acid usually is used to etch the internal surface of the ceramic restoration (Naves et al., 2010). HF is applied after the tray-in paste been copiously rinsed with water spray (Figure 1). Such acid increases surface relief resulting in micromechanical bonding of resin cement to ceramic restoration (compare Figure 2 and Figure 3) (Filho et al., 2004; Lise et al., 2015). In some countries HF etching is done by the dental laboratory (Swift Jr, Sturdevant \& Boushell, 2013). Pre-treatment conditioning with HF in feldspathic ceramic and leucita reinforced glass-ceramic will result in an internal surface with whiteopaque appearance.The clinician should check the internal surface of the restoration in order to confirm the etching, which is similar to acidetched enamel (Swift Jr, Sturdevant \& Boushell, 2013). HF reaction results in salt formation (Belli et al., 2010). Such debris formations are more common to occur in feldspathic porcelain (Figure 4a) and leucita reinforced glass-ceramic treated with 10\% HF (Figure 4b). Proper HF application on lithium disilicate glass-ceramic (LD) will not result in this deposit formation (Figure 4c) and clinical appearance after ultrasonical cleaning in distilled water will be clear (see Figure 9). If a clinician works in a country where HF use is banned, he or she should visit dental laboratory to make sure that they are applying HF as per the ceramic manufacturer instructions. Chair side ceramic etching can be done with a brief application of 5 to $10 \% \mathrm{HF}$ acid on the internal surfaces of the inlay, onlay or veneer (Figure 5). Application time depends on the type of ceramic material being used (Swift Jr, Sturdevant \& Boushell, 2013). HF etching time for e.max Press and e.max CAD (IvoclarVivadent) is $20 \mathrm{sec}$ as per the manufacturer instructions. Then LD surface is thoroughly rinsed with water spray (Figure 6), HF must be rinsed with a gauze and then be disposed properly in Hazardous Waste. We recommend to perform this procedure in a rubber to protect the contact lens veneer to fall and crack. LD surfaces are cleaned ultrasonically for $180 \mathrm{~s}$ in distilled water (Figure 7) and air-dried for 60s. Ceramic internal surface is treated with a silane coupling agent to facilitate chemical bonding of the resin cement (Filho et al., 2004). A solution of silane $+10 \mathrm{MDP}$ (Monobond Plus, Ivoclar Vivadent) is applied for 60s (Figure 8) and the excess dispersed with a vigorous stream of air as per the LD manufacturer's instructions (Figure 9). Others silane coupling agents results in similar immediate resin cement bond strength to LD (Pottmaier, Linhares \& Lopes). However, bonding durability still need further investigations. 


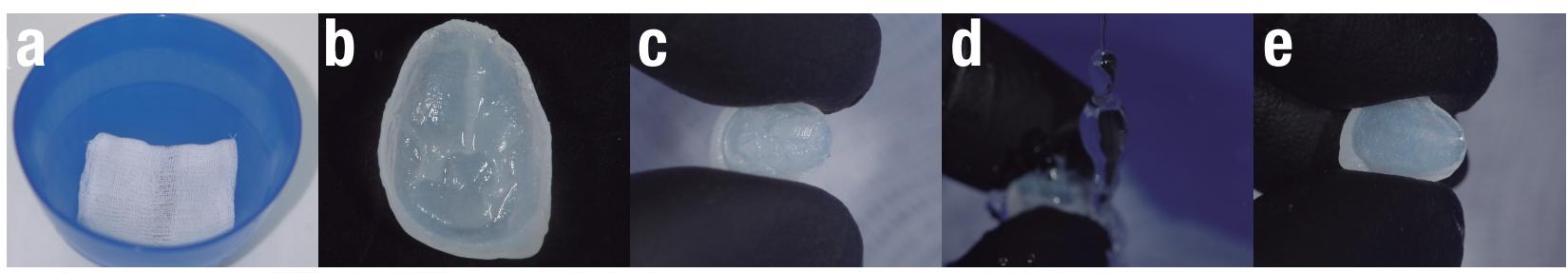

Figure 1.

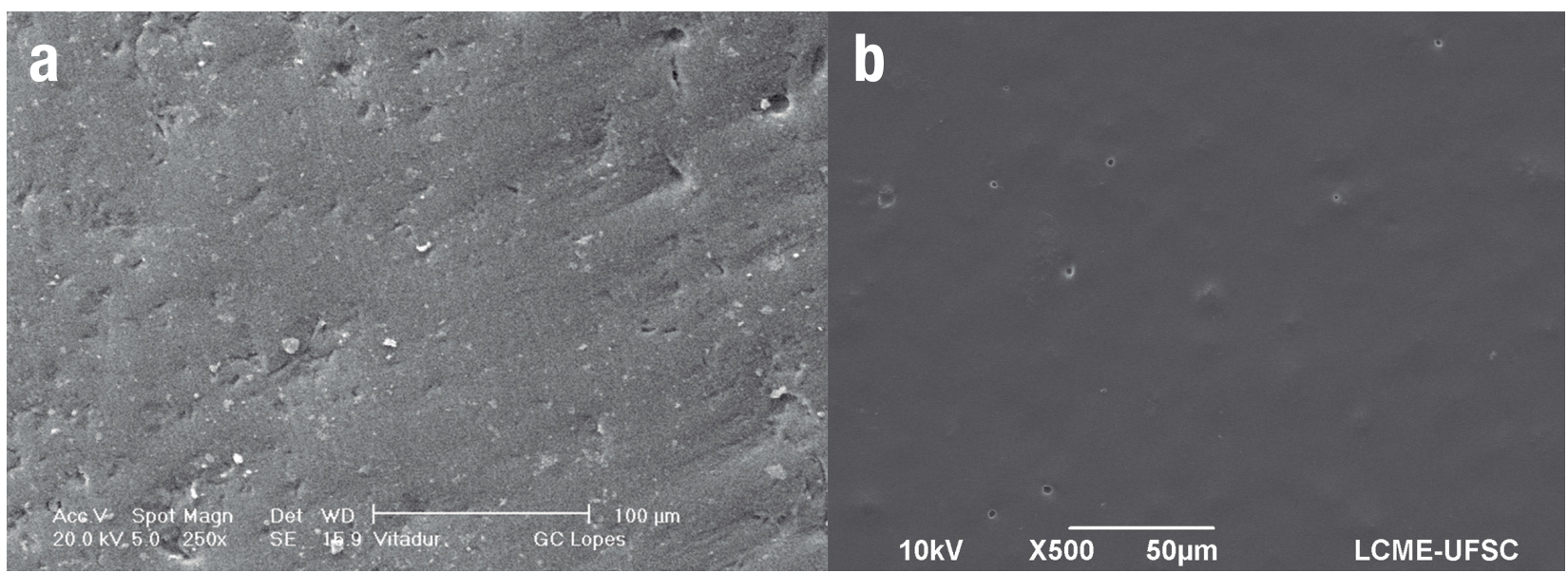

Figure 2.

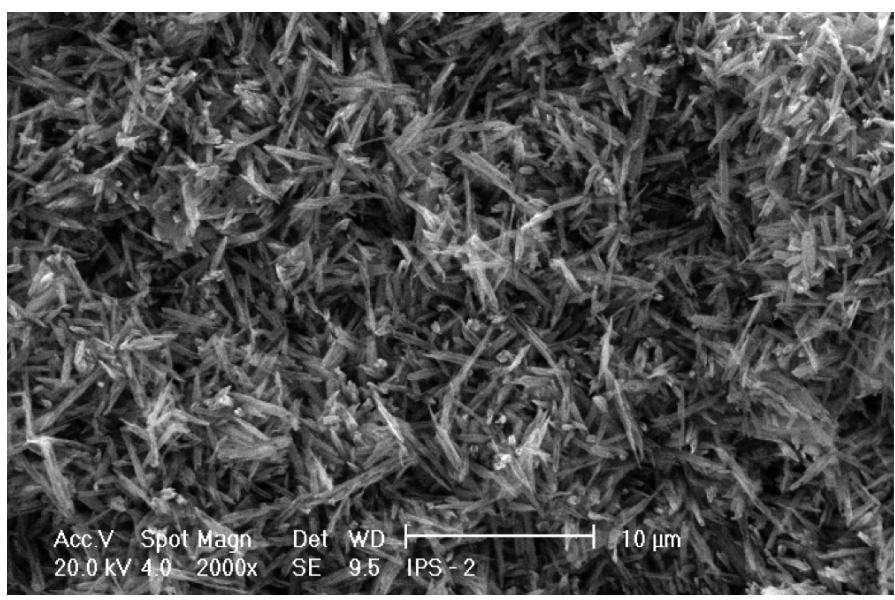

Figure 3. 


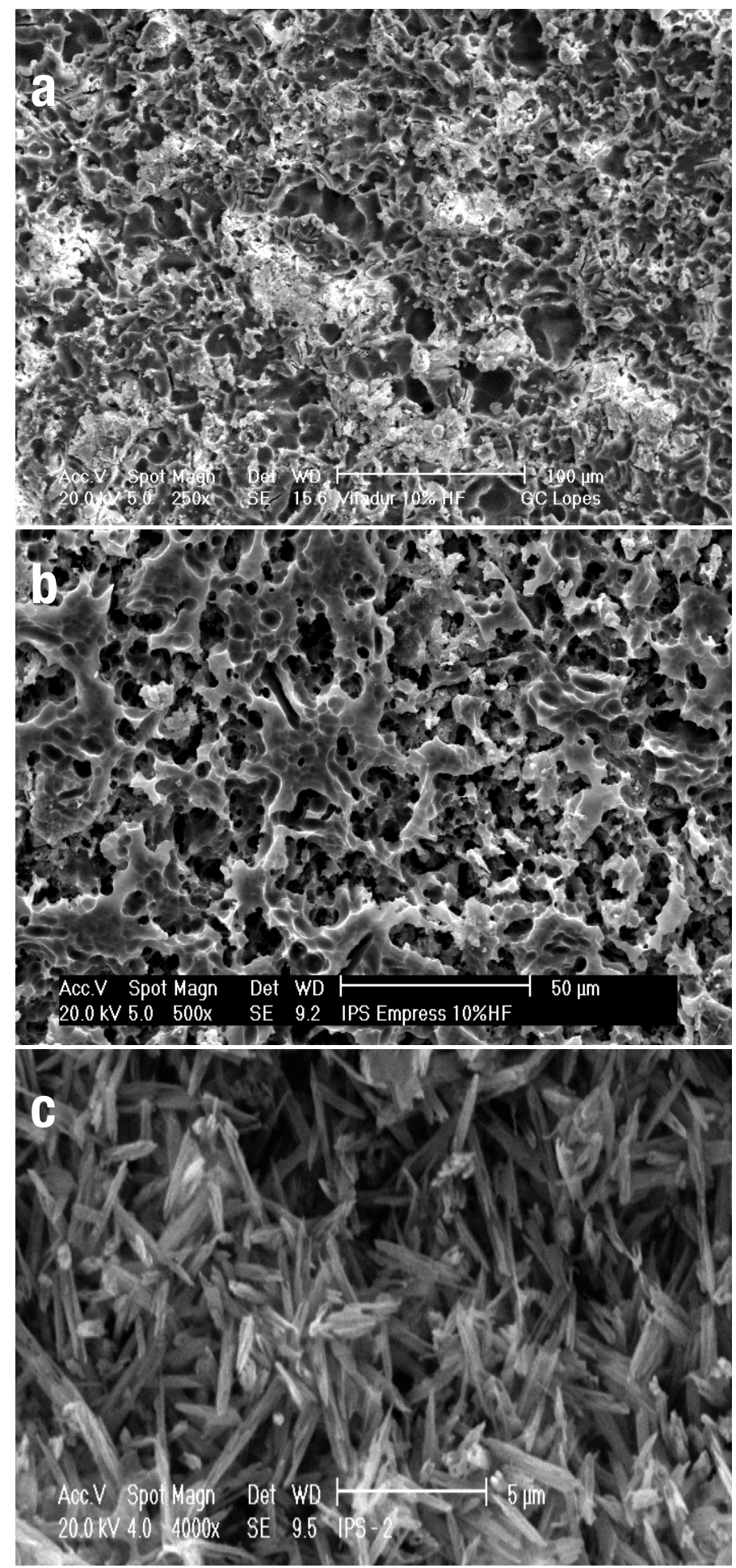

Figure 4. 


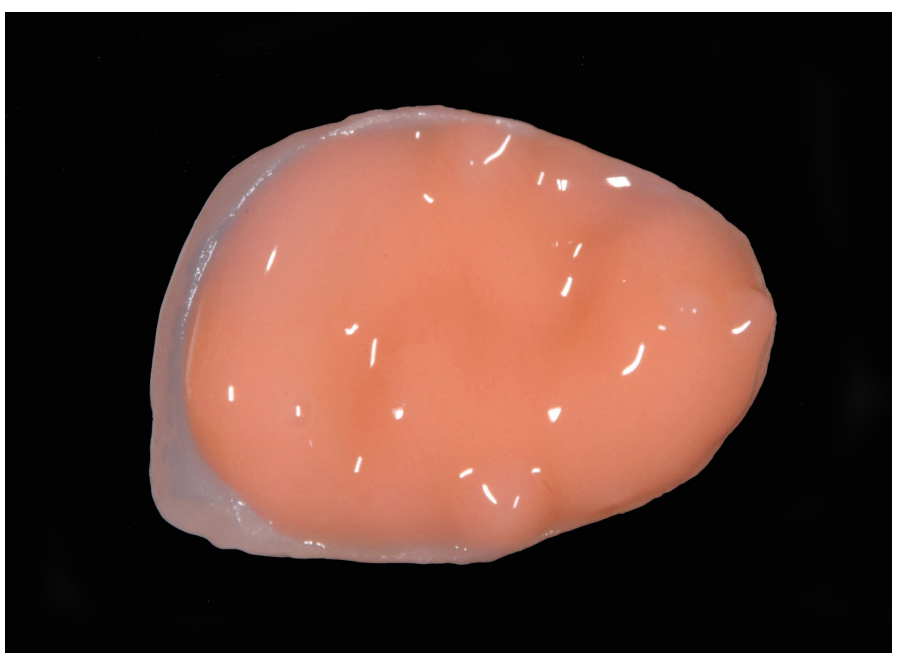

Figure 5.

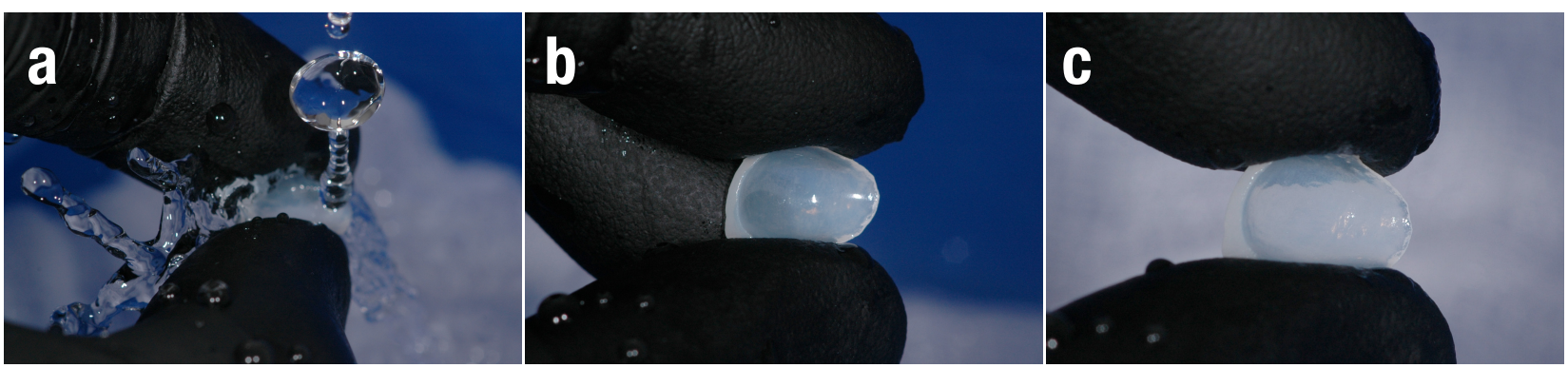

Figure 6.
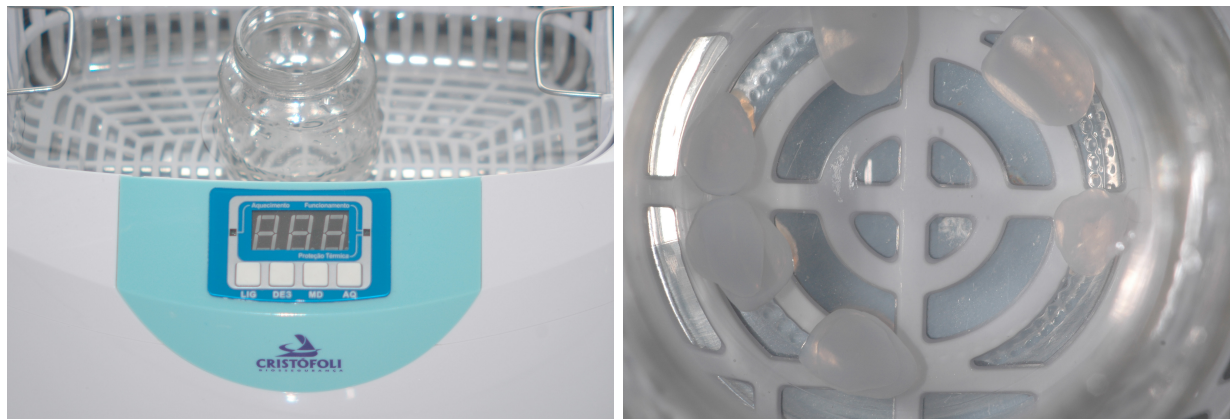

Figure 7. 

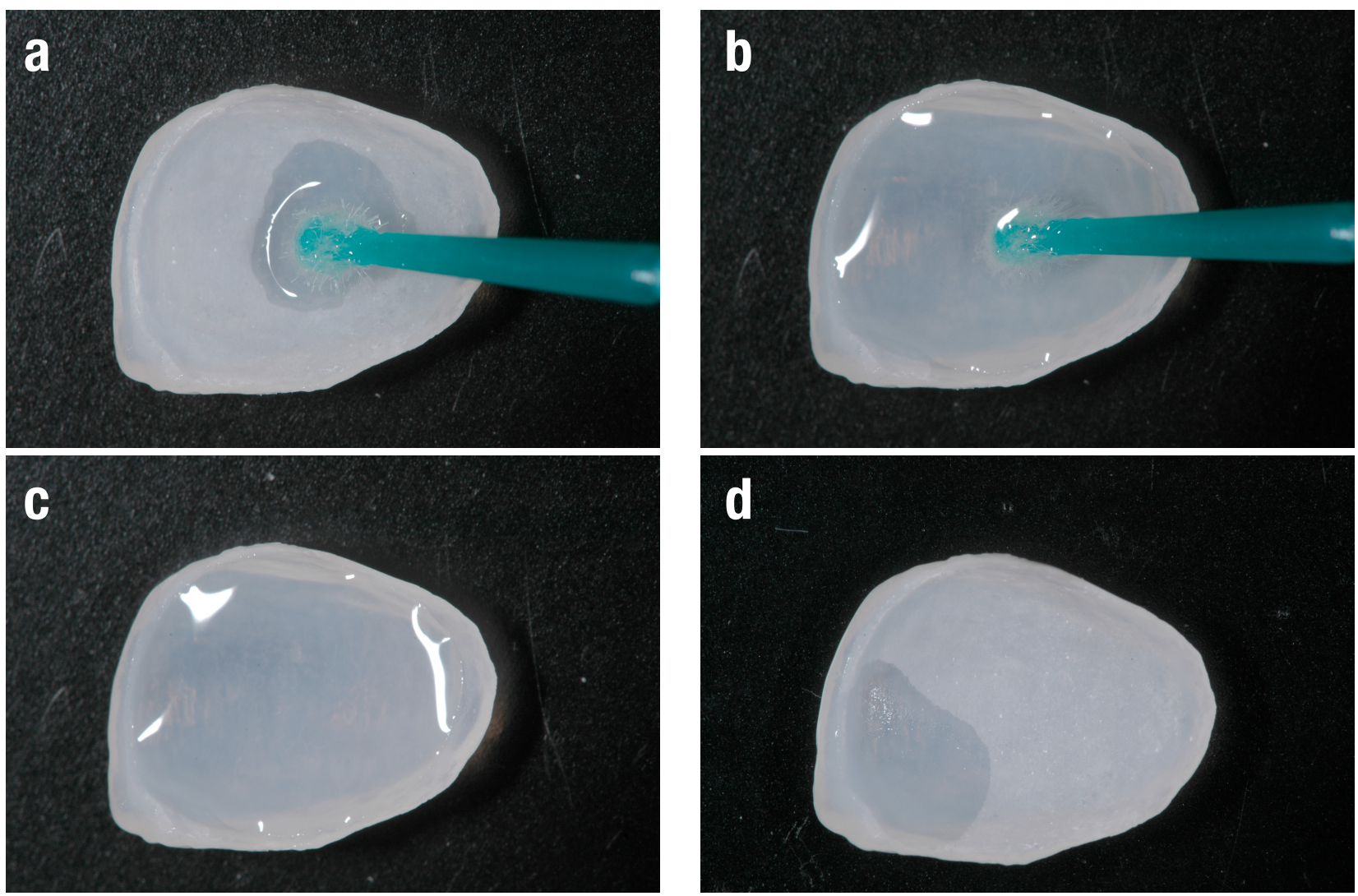

Figure 8.

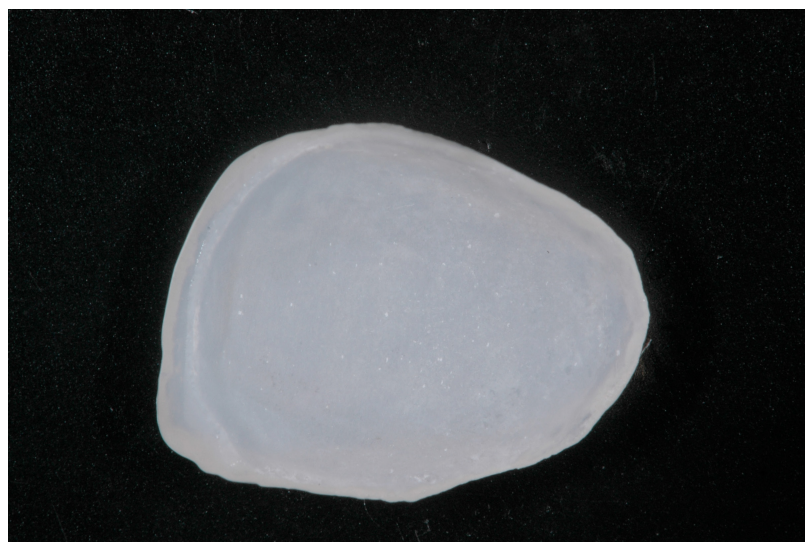

Figure 9.

WHY HF IS CONSIDERED SO DANGEROUS?

Hydrofluoric acid is a "weak" inorganic acid (Blodgett, Suruda \& Crouch, 2001). This chemical classification seems to be ironic, because HF is one of the most dangerous acids known. HF was primarily used in industrial processes: glass etching, metal cleaning, and laboratory reagents. It has distinct ability to dissolve glass (Blodgett, Suruda \& Crouch, 2001; Pam, 2015). It needs to be treated differently than even strong acids like Sulfuric and Hydrochloric. HF is an acid like no other. It is so potent that contact with it may not even be noticed until serious damage has been occurred. Even very strong acids, and mixtures of 
acids, do not have the power to cause death and injury in the way that HF Acid can (University of Washington, 2015).

HF has two mechanisms that cause tissue damage (Hatzifotis et al., 2004):

1.Corrosive Burns from free hydrogen ions.

2.Chemical Burns from tissue penetration of the fluoride.

HF differs from other acids because the fluoride ion readily penetrates the skin, causing destruction of deep tissue layers, including bone. Pain associated with exposure to solutions of HF (1 to $50 \%$ ) may be delayed for 1 to 24 hours (Hatzifotis et al., 2004). If HF is not rapidly neutralized and the fluoride ion bound, tissue destruction may continue for days and result in limb loss or death. HF is similar to other acids in that the initial extent of a burn depends on the concentration, the temperature, and the time of contact with the acid (Hatzifotis et al., 2004).

In dentistry, it is used as a porcelain/ceramic surface conditioner. Its use should be done with caution (see Table 1). Care should also be observed on our clinic environment, because an unintentional application or spit can corrode metals and ceramics, as the metal surface of the triple syringe, our work bench made of Corian $®$ (DuPont), porcelain floors, etc. It is noteworthy that the dissolution process does not rely on the "acidic" property of HF, relies on the fluoride substitution to oxygen due to electronegativity in glass which forms the Si.F glass. Thus, the term "acid etch" is misleading and therefore "HF etching" is preferred (Tian et al., 2014).

Hydrofluoric acid is caustic if not buffered, thus most commercials HF used in dentistry are buffered. Buffered HF's are safer because they are less corrosive due to minor free hydrogen ions. However, treatment of the ceramic surface is less retentive (Perdigão, Ballarin \& Lopes, 2015).
HF's not buffered are indicated to use only in the dental laboratory, not in dental office. Even though commercial presentations are diluted (2.9\%, 4.8\% and $9.6 \%$ hydrofluoric acid), buffered and incorporated into a gel, we highly recommend to manipulate this product as very corrosive (Pulpdent, 2015).

HF $(10 \%)$ is prohibited in some countries. In others, its use is free. In Europe, there are several constraints for more than $7 \%$ concentrations. Thus, European dental materials companies present HF in lower concentrations than $7 \%$, which contributes to minor the costs of transportation and the handling benefits with less costly disposal, as well as lessen the risk of serious accidents. For this reason, some dental materials companies with worldwide representation have the two concentrations in its portfolio ( $\approx 5 \%$ and $\approx 10 \%)$. In the USA, the dentist decides if their ceramic restorations should come or not conditioned with HF by Dental Technician. If the clinician do not communicate, the ceramic pieces are conditioned. In Japan about 30 years ago some dentist made a mistake to apply accidently HF on children's teeth instead of sodium fluoride. The patient died. From that time, Japanese dentist can't buy HF to etch ceramic, thu the dental Laboratory applies HF on ceramic before sending the piece to dentist.

Some commercial products are available in plastic bottles, especially those that are produced by dental ceramics manufacturers. Most syringes are sold in 2.5 to $4 \mathrm{ml}$ with disposable tips which facilitate application. Plastic tips are better because the metal corrodes, especially by nonbuffered HF's. HF associated with $10 \%$ sulfuric acid is found in a commercial brand (Vita, 2015).

In dentistry, when HF was used for the first time to etch ceramic, a high concentration solution (HF 52\%) was employed (Calamia, 1983). If HF is used as a viscous gel and stained with pigments become safer because they are less volatile and more easy to control the area of application due 
to visual contrast. Currently, HF gels syringes at lower concentrations are commercially available from several dental materials industries.

Ceramic conditioning with HF associated with the application of a silane agent is the intra-oral repair protocol recommended for restoring fractured ceramic surface with composite resin, due to previous results showing greater retention of the composite resin applied. The potential damage to patient's health by HF negligent use due to acid toxicity (especially during intraoral repair), besides some indications recommended by HF manufacturers of products indicating its exclusive extra-oral use (Vita, 2015); has motivated dental research focus in testing alternative protocols based only in surface modifications produced by sandblasting and chemical union promoted by silane agents (Spohr et al. , 2003; Aida, Hayakawa \& Mizukawa, 1995; Yoshida, Yamashita \& Atsuta, 2005) and/ or adhesive systems especially those containing MDP in its composition (Lise et al., 2015; Kalavacharla et al., 2015). However, this is another topic that lacks of scientific studies that simulate durability or long term clinical success.

Table 1. Recommendations for HF manipulation

Do not use latex gloves.

At a minimum, double Nitrile gloves (4 mil thick) or butyl rubber gloves are strongly recommended even when working with small quantities of HF.

Prefer lower concentrations. 5\% HF condition lithium disilicate ceramic as efficient as 10\% HF.

Prefer plastic facial mask.

The use of protective glasses is mandatory, because HF eye contact will result in severe damage with concentrations greater than $0.5 \%$.

Purchase HF in limited quantities. Do not storage major amount of HF in the office. HF concentration depends on the way the product was maintained.

HF must be rinsed with a gauze and then be disposed properly in Hazardous Waste.

Never use Hydrofluoric Acid when working alone or after hours.

Keep HF refrigerated. HF is highly volatile. In gel form will be volatile at temperatures above $280 \mathrm{C}$.

Do not leave HF exposed to sunlight.

The Hydrogen Fluoride molecule is so mobile that it may easily pass through the skin. Because Fluorine has an extremely high affinity for Calcium, bones will be attacked. Moreover, there may be no pain immediately after the burn, leading the injured person to believe that they are not in danger.

Wash all exposed areas with copious amounts of water.

Application of 2.5 to $33 \%$ calcium gluconate or carbonate gel into the burn area is recommended. Use calcium gluconate for dermal treatment only. Apply the gel after putting on double Nitrile gloves (4 $\mathrm{mm}$ thick or thicker).

Immersion of the ceramic contact lens in silicone (putty viscosity) during and after etching with HF is highly contraindicated, because the roughness formation on the inner surface can lead to crack propagation at the time of adhesive cementation.

\section{REFERENCES}

Aida M, Hayakawa T, Mizukawa K. Adhesion of composite to porcelain with various surface treatments. J Prosthet Dent. 1995;73:464-70.

Belli R, Guimarães JC, Filho AM, Vieira LC. Postetching cleaning and resin/ceramic bonding: microtensile bond strength and EDX analysis. J Adhes Dent. 2010;12:295-303.

Blodgett DW, Suruda AJ, Crouch BI. Fatal unintentional occupational poisonings by hydrofluoric acid in the U.S. Am J Ind Med. 2001;40:215-20.

Calamia JR. Etched porcelain facial veneers: a new treatment modality based on scientific 
and clinical evidence. N Y J Dent. 1983; 53:255-259.

Filho AM, Vieira LC, Araújo E, Monteiro Júnior S.

Effect of different ceramic surface treatments on resin microtensile bond strength. J Prosthodont. 2004;13:28-35.

Hatzifotis M, Williams A, Muller M, Pegg S. Hydrofluoric acid burns. Burns. 2004 Mar;30(2):156-9.

Hill TJ, Tysowsky GW, Costantino D. Cementation effect on the fracture load of two CAD/CAM materials. J Dent Res 88 (Spec Iss A): Abstract \# 52, 2009.

Ivoclar Vivadent. Retrieved on: July 07, 2015: http://www.ivoclarvivadent.us/en-us/p/all/ products/all-ceramics/all-ceramics-chairside/ cementation-and-care.

Kalavacharla VK, Lawson NC, Ramp LC, Burgess JO. Influence of etching protocol and silane treatment with an universal adhesive on lithium disilicate bond strength. OperDent. 2015;40:372-8.

Lise D, Perdigão J, Van Ende A, Zidan 0, Lopes G. Microshear Bond Strength of Resin Cements to Lithium Disilicate Substrates as a Function of Surface Preparation. OperDent. 2015 Mar 6

Lopes GC, Perdigão J. Effect of HF concentration/etching time on adhesion to lithium disilicate. J Dent Res 94 (Spec Iss A): Abstract \#791, 2015.

Naves LZ, Soares CJ, Moraes RR, Gonçalves LS, Sinhoreti MA, Correr-Sobrinho L. Surface/ interface morphology and bond strength to glass ceramic etched for different periods. OperDent. 2010;35:420-7.
Pam Koontz, Hydrofluoric Acid Safety, University of Tennessee, Knoxville, 14-07-2015: http:// web.utk.edu/ ehss/training/has.pdf.

Perdigão J, Ballarin A, Lopes GC. FESEM analysis of lithium disilicate treated with three HF concentrations. J Dent Res 94 (Spec Iss A): Abstract \#2324, 2015.

Pottmaier LF, Linhares LA, Lopes GC. Effect of silane coupling agent on microshear bond strength to lithium disilicate.J Dent Res 94 (Spec Iss A): Abstract \#, 2015.

Pulpdent Inc. July 07, 2015: <http://www.pulpdent. com/product-category/category/etching/ pulpdent-etch-gel/.

Spohr AM, Sobrinho LC, Consani S, Sinhoreti MA, Knowles JC. Influence of surface conditions and silane agent on the bond of resin to IPS Empress 2 ceramic. Int J Prosthodont. 2003;16:277-82.

Swift Jr EJ, Sturdevant JR, Boushell LW. Indirect tooth-colored restorations. Cap. 11 . Sturdevant's Art and Science of Operative Dentistry, 6th Ed. In: Heymann HO, Swift Jr EJ, Ritter AV. 2013

Tian T, Tsoi JK, Matinlinna JP, Burrow MF. Aspects of bonding between resin luting cements and glass ceramic materials. Dent Mater. 2014;30:e147-62.

University of Washington. Hydrofluoric Acid. Environmental Health and Safety TIPS. University of Washington. May, 2000.

Vita Inc. July, 07 2015: http://www.vita.com/ product-category /etching/vitaceramicetching. Yoshida K, Yamashita M, Atsuta M. Bond strength between machinable glass-ceramic and dualcured resin luting cements using silane coupling agents. Am J Dent. 2005 0ct;18(5):327-30.

\section{Guilherme Carpena Lopes DDS, MS,PhD ${ }^{1}$; Andressa Ballarin DDS ${ }^{2}$}

1. Associated Professor, School of Dentistry, Federal University of Santa Catarina, Brasil. 2. Director, MUDE Odontología, Brasil.

Prof. Dr. Guilherme Carpena Lopes, Rua Laurindo Januário da Silveira no 947, apto 34A, Lagoa da Conceição, 88062-200 Florianópolis, SC, Brasil. Tel: +55-48-3232-1816. Fax: +55-48-3222-0734 e-mail: guilhermelopes@ccs.ufsc.b

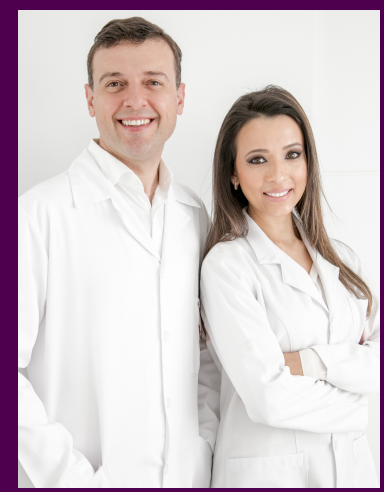

